tests as in cases of supposed hanging. If there be fractures of the vertebre of the neck, but no dislocations, there is reason for supposing that the death was effected by strangulation rather than by hanging; nevertheless, this admits of a fallacy, as occurred in the case of Sir EDMund GodFREY, who was murdered on the 12th of October, 1677, by strangulation. A handkerchief was twisted round his neck, but on the supposition of one of the murderers, that the purpose was not effectually accomplished, the neck was violently twisted round, and dislocation produced. Sometimes, when the hands are employed, one small bruised spot only is perceptible on the neck. MetzyFr mentions an instance of this kind. A young officer was strangled in bed by a soldier. The surgeon of the regiment, who examined the body, could find one small spot only, which was explained by the confession of the murderer, that he had killed his victim by violent pressure with his thumb on the trachea.

"A young man, eighteen years of age, and named Bartholomew Pourpre, was found dead, and hanging on a tree, at seven o'clock in the evening, on the 12th of $\mathrm{Au}$ gust, 1736. A surgeon, who examined the body, certified that he had been strangled. His father had married a second wife, who was on very ill terms with the young man, and had produced frequent quarrels and disputes, and threats of murder between them. Suspicion, therefore, was excited, but its probability was destroyed by the idea that a father would not murder his own son, and also from the circumstance that he was fifty-two years old, and his son eighteen, in full health and vigour. On this reasoning the father was acquitted, and the son was deemed to have hung himself. An order having, however, been made to prepare a statement of the suicide, and the case being carried up to the parliament at Aix, the attorney-general disoovered such facts in the statement of the surgeon, as led him to believe that Pourpre had not destroyed himself; it was mentioned, not only by him, but by other witnesses, that the mark of the cord, instead of being at the upper part of the neck, was at its lower part, just above the shoulder, and that the teeth were knocked in, and bloody, The parliament, therefore, from these facts, decided that the father had strangled him, and had put his foot in the mouth of his son, either to prevent the cries, or to hurry on the strangulation. The suspension, they declared, was subsequent to his death. Whether the father was guilty or not, we may, at least, say with Fodere, that two facts are well established in this case ; first, that the son had been strangled before being hung; and second, that the strangling had been done by others."*

\footnotetext{
* Foderé, vol. iii. p. 152, cited from Louis.
}

With regard to the question, can stran. gulation be an act of suicide? we might, $d$ priori, reply, that it is impossible, as the asphyxia which is caused by strangulation must deprive the man who attempts it of all con. trol over his muscular energies; and, consequently, the act could never be completed yet cases are recorded which appear opposed to this opinion. Dr. Desgranges, of Lvons, relates a case of a man found in a hay-loft, who had strangled himself by means of a handkerchief, tightened by a stick; and Dr. Dunlop relates another, on the authority of a surgeon of the navy, which occurred on board a ship of war in India. A Malay tied a handkerchief round his neck, and with a small stick twisted it several times, and then secured it from untwisting, by placing the stick behind his ear. However extraordinary such a de termined resolution to commit suicide may be, there can be no doubt that, when the resolution to commit self-destruction is once taken, and the means are fixed upon, no want of voluntary power to execute the determination is ever found absent; on the contrary, the various means adopted by the suicide to secure his purpose are most extraordinary, and are rendered credible only by the extent and respectability of the testimony in support of their employment.

\section{DIVISION OF THE TENDO-ACHILLIS FOR} THE CURE OF DEFORMED FOOT.

\section{To the Editor of THE LANCET.}

Sir:-The attention of the "Royal MedicoChirurgical Society," has lately been directed, by a paper from Mr. Whipple of Plymouth, to the division of the tendo-achillis in certain deformities of the foot, and I see that, by some of the members, that operation is considered to be, occasionally, not deroid of serious consequences. On the other hand, there are some who regard it as a proceeding which is simple in execution, unattended by danger, and productive of speedy and permanent benefit. No one, I should imagine, ean read the testimony which Dr. Little has lately offered in its favour, without inclining to the latter opinion. He remarks, " that it must ultimately take its place in our class-books of surgery;" and " that success, based on numbers of facts, will speedily prevail." With a view, then, of placing on record another case in which it has been successfully performed, withont the occurrence of any untoward symptoms, I beg of yon to find space in an early number of your $J_{0 u r}$. nal for the following statement:-

W. Linton, a robust, healthy child, now three years old. I was present at his birth, and noticed the deformity before quitting his mother's apartment. Within one month I 
commenced my attempt to remedy it, by means of bandaging and splints, but after fifteen months' trial nothing was gained, although continued with perseverance deserving of better success. The child was then allowed to walk, assisted by such mechanical support as is usually employed in similar cases; the deformity, in fact, was abandoned to the care of the instrumentmaker. Having, through the friendship of Mr. Whipple, witnessed the successful treatment of his first case, I was induced to recommend it in this instance. I need not occupy your columns by a description of the deformity. It was one of common occurrence, the limb, resting on the dorsal surface of the cuboid bone, the sole towards the opposite leg, and the os calcis drawn up above the level of the outer ancle. The operation was performed on the 21st of Jannary, and in three weeks it was evident that union had taken place between the divided ends of the tendon. For the first fortnight, a tight handage, and a splint to steady the limb, were the only means employed, but after that period the bandages were drawn firmer, and the heel was kept. permanently lowered. At the expiration of the fifth week, the child was able to walk across the room, without the aid of artificial support, and is now fast acquiring the perfect use of his limb. I have been thus brief in relating this case, because there is nothing in it to add to the recorded opinions of $\mathbf{D r}$. Little. I have, however, lately seen some few cases operated on by Mr. Whipple, which promise to add much to our store of experience on the subject, and not a little to the well-merited reputation of that gen. tleman, in the management of such severe affictions. I am, Sir, your's obediently, JOSEPH WELLS,

Memb. Royal College Surg. Plymouth, 22d April, 1837.

\section{EUMBAGO TREATED BY ACUPUNC- TURATION.}

Ta the Editor of THE LANCET.

SIR:-Mr. J. H., of Dartford, was con. fined, during six weeks, to his bed and room, by a severe attack of lumbago, for which he was treated secundem artem, i. e., leeched, cupped, and blistered, taking calomel, opium, colchicum, \&c., \&c., \&c., in all legitimate forms, but with none effect.

I found him suffering from a fixed pain in the longissimi dorsi, extending to one-third of their length from the sacrum, the almost invariable seat of lumbago. I waited some time for the medical gentleman who was attending Mr. H., and on his arrival proceeded to perform the following operation :Three needles were introduced into the left muscle, (where the pain was greatest), and suffered to remain during about five minutes The right muscle was operated on in the same manner. Very little pain was experienced; I should say, comparatively none.

Mr. H. immediately afterwards aressed himself, and walked a distance of upwards of seven hundred yards, to the great delight and astonishment of himself and his relatives, who were amazed at the wonderful effect of this simple remedy; and its effects certainly are wonderful; they require the evidence of ocular demonstration to be accredited to their full extent. Why, I would ask, is this simple remedy not more resorted to in those chronic, fixed, muscular pains, (and often in acute cases), which defy the power of medicaments, and often compel the puzzled practitioner to pass his paralyzed patients, if not to the "Houris," at least to " $\mathrm{Ma}$ homed's paradise of steam and shampooing," to soothe their sufferings in the saline sudatories of the sable prophet " with what benefit they may?" Is it because the remedy of acupuncturation is infra dig., or is it because it does not pay? I cannot for a moment indulge in the latter supposition, and the former is unjust. I can only say I was so well paid by Mr. H., that I should have no objection to a few such patients " prore nata."

In former papers* I directed the attention of the profession to acupuncture; $I$ also published several consecutive cases, in which " the crooked were made straight, and the lame to walk." In one case the sight was restored. I remain, Sir, your obedient servant,

Fulham, April 22, 1837.

T. W. WassBrough.

\section{COMPOUND LUXATION OF THE HUMERUS.}

\section{To the Editor of The LANCET.}

Srr:-On looking over my last monthly packet of THE LANCET, which I have just received from my bookseller, I see that you have inadvertently made a mis-statement on the cover of the Number for March 4, 1837, in these words, "Case of Compound Luxation of the Humerns, by P. T. Scott, Esq. surgeon, Whitchurch." May I request the favour of your correcting it, by inserting, that Mr. Scott, instead of being my " assistant," is my apprentice, and, consequently, not a surgeon.

There is also a mis-statement in his report of the case, which he made without my knowledge. He says, "that amputation was thought necessary." Here he has erred, through his not having been present at a

* Lancer, Vol. X., p. 846 ; Vol. XI., 1828, p. 366. 